\title{
Ekotuotteistamisen vihreä markkinointimalli - pienyritysten mahdollisuudet ja keinot
}

\author{
Maarit Pallari ${ }^{1}$ ja Sari Forsman², \\ ${ }^{1}$ MTT/Taloustutkimus, Luutnantintie 13,00410 Helsinki,maarit.pallari@mtt.fi \\ ${ }^{2}$ MTT/Taloustutkimus, Luutnantintie 13,00411 Helsinki, sari.forsman@mtt.fi
}

\section{Johdanto}

Ympäristöarvoiltaan erilaistetut tuotteet ja palvelut tarjoavat uusia markkinointimahdollisuuksia erityisesti maaseudun pienyrityksille. Ympäristöarvoilla tarkoitetaan sellaisia yrityksen arvoja, jotka liittyvät tuotteen tuottamiseen tietyssä paikassa ja tietyssä ympäristössä. Koska maaseudulla sijaitseva yritys on yritystoiminnan kautta sidoksissa sekä yritysympäristön kulttuuriin ja sosiaalisen vuorovaikutuksen kautta arvoympäristöön, arvosidonnainen tuotteistaminen voidaan nähdä maaseutuyrityksen tuotteistamisen vahvuutena. Tässä tutkimuksessa ympäristöarvoja tarkastellaan humanistisen ja teknologisen näkökulman kautta. Ympäristöarvoja voidaan jaotella yhteisöllisiin ympäristöarvoihin ja yksilön ympäristöarvoihin. Esimerkkejä yhteisöllisistä ympäristöarvoista ovat eettiset tuotantotavat, paikallisuus, säästävämmän tekniikan käyttö, ympäristöystävälliset tuotantotavat, kierrätys, maaseutumaiseman ylläpitäminen ja hoito sekä luonnon biodiversiteetin huomioon ottaminen yritystoiminnassa. Esimerkkejä yksilön ympäristöarvoista ovat eettinen toiminta suhteessa omaan lähiympäristöön ja ympäristökasvatuksen korostaminen työyhteisössä. Ympäristöarvoiltaan erilaistettuihin tuotteisiin voi sisältyä sekä yhteisössä että yrityksessä vallitsevia arvoja ja asenteita.

Ympäristöarvojen tuotteistaminen vaatii kokonaan uudenlaisten tuotantotapojen omaksumista sekä innovatiivista tuotekehitystä ja markkinointia. Ympäristöasioiden ja -arvojen merkitys markkinoinnissa on kasvanut viime vuosina. Myös yhä useammat pk-yritykset ovat alkaneet panostaa ympäristöaloitteisiin strategisena kilpailukeinona. Ympäristömyötäinen tuotteistaminen edellyttää moniulotteista käsitystä sitä, mitkä tekijät tuotteistamiseen vaikuttavat ja miten niitä voidaan painottaa niin markkinoinnin kuin koko yritystoiminnan suunnittelussa ja uudelleensuuntaamisessa. Ilmiön ja ongelmakentän tunnistaminen ja ymmärtäminen ovat pienyritykselle avainasioita ympäristömyötäisten markkinointistrategioiden suunnittelussa ja toteuttamisessa.

Tutkimuksen tavoitteena on luoda markkinointimalli ympäristöarvoiltaan erilaistetuille maaseudun pienyritysten tuotteille ja palveluille. Tavoitteena on auttaa maaseudun pienyrityksiä tuotteistamaan ja markkinoimaan tuotteitaan ja palvelujaan ympäristöarvojen näkökulmasta, markkinointiargumenttien valinnassa, kohderyhmän määrittelyssä ja markkinoiden segmentoinnissa, markkinointikanavien valinnassa, hintastrategiapäätöksissä sekä markkinointiviestinnässä. Lisäksi tavoitteena on erityisesti tuoda esille niitä rajapintoja, jotka voivat muodostua pienyrityksen ekotuotteistamisen kompastuskiviksi. Tutkimuksen tarkoituksena on parantaa ympäristömarkkinoinnin edellytyksiä maaseudun pienyrityksissä ja siten parantaa maaseudun pienyritysten kilpailukyvyn ja menestymisen edellytyksiä markkinoilla. Tämä edistää osaltaan maaseudun elinvoimaisuutta ja kestävää kehitystä.

Tutkimus on osa MTT:n (Maa- ja elintarviketalouden tutkimuskeskus) koordinoimaa Rural LIFE Design -hanketta (2001-2004). Hankkeen tavoitteena on rakentaa maaseudun tuotteiden, palveluiden ekotuotteistamiseen toimintamalli (www.mtt.fi/ecodesign). Myöhemmin hankkeesta ilmestyy opas pienyrittäjille.

\footnotetext{
Aineisto ja menetelmät

Tutkimusote on fenomenologinen, koska ympäristöarvot ovat käsitteiltään moniulotteisia ja vaikeasti tavoitettavia ja taipumuksemme luokitella, vertailla ja jäsentää sopii ajoittain huonosti teknologiaorientoituneeseen käsityskarttaamme. Fenomenologia palvelee erityisesti juuri uuden tiedon ja tieteiden soveltamista, josta markkinointimallin kehittämisessä on kysymys.

Ympäristöarvojen markkinointimallia on rakennettu yhteistyössä neljän pilot-yrityksen kanssa. Yritykset edustavat maaseutuelinkeinojen eri aloja. Markkinointimallin rakentamisen pohjaksi valittiin kustakin yrityksestä yksi tuote. Tuotteet olivat palvikinkku (Makuliha Oy), hevostalli (FM-Haus Oy), kalan elinkaari (T:mi Tammelan Kala-Apaja) ja kasvihuonekurkku (Kiipulasäätiö). Tutkimusaineistoa hankittiin haastattelemalla yrityksen edustajia sekä tutkimalla yrityksistä kirjoitettuja lehtiartikkeleita, markkinointimateriaalia ja yritysten www-sivuja. Lisäksi jokaiselle pilot-yritykselle tehtiin asiakaskysely. Haastatteluosio tehtiin teemahaastattelumenetelmällä (Hirsjärvi \& Hurme 1988). Teemahaas-
} 
tattelumenetelmän käyttö antoi mahdollisuuden teemojen sisällä olevien asioiden keskinäisen järjestyksen säätelyn ja tulkintojen täsmentämisen.

Pilot-yritysten edustajien haastattelut suoritettiin teemahaastattelumenetelmällä. Teemat muodostettiin yritysten esiselvitysmateriaalia (lehtiartikkelit, markkinointiesitteet, kotisivut) apuna käyttäen seuraavasti:

- Yrittäjyys; perheyritys, säätiö, itsellinen yrittäjä, kumppanuus

- Asiakkuus; asiakkaiden tuntemus, vakioasiakkuus, asiakkaan palvelut, sitoutuneisuus

- Tuotteen markkinoitavuus; markkina-alueen tuntemus, markkinointikanavat, mahdollisuudet

- Ympäristötietoisuus; suhtautuminen ympäristöön, ekotuotteistamiseen

Aineistojen analysoinnissa sovellettiin kvalitatiivista tutkimusotetta (Alasuutari 1994, Eskola \& Suoranta 1998, Hirsjärvi ym. 2000). Tutkimusaineiston käsittelyn lähtökohdaksi otettiin Crawfordin (1996) näkemys siitä, että markkinointistrategiaan voidaan sisällyttää ns. uuden tuotteen käsite, jossa jo markkinoilla olevaa tuotetta tutkitaan ikäänkuin. uutena markkinointituotteena. Näin saatu ajatteluperusta siirrettiin ekotuotteistamisessa esitettyyn kansainväliseen elinkaariajattelulähtöiseen markkinointimalliin (Charter \& Polonsky 1999). Mallia on sovellettu tulosten tarkastelussa ja johtopäätösten esittämisessä.

Markkinointimallin rakentamisen taustalla oli käytettävissä myös Rural LIFE Design -hankkeessa tehdyt elinkaarilaskelmat kullekin pilot-yrityksille.

\section{Tulokset ja tulosten tarkastelu}

Markkinointimallin rakentamisen lähtökohtana oli pilot-yritysten tuotteet, joita tarkasteltiin Crawfordin (1996) näkemyksen mukaan ikään kuin uusina markkinoilla olevina tuotteina. Uuden tuotteen markkinointistrategiaan kuuluu kolme ulottuvuutta: oikea laatu, oikeaan aikaan ja oikealla hinnalla. Kun tuote otetaan kehittämisen kohteeksi, se on sidoksissa käytettävissä olevaan aikaan, resursseihin ja tuotteen laadulle asetettaviin kriteereihin. Laadun, hinnan ja ajan kautta kirjataan ympäristöarvoiltaan erilaistettavan tuotteen kehittämisen tavoitteet ja päämäärät. Tällöin tavoitteet ja päämäärät tulevat selkeästi ja avoimesti kirjatuksi, jolloin kehittämisen rajat ovat kaikkien toimijoiden tiedossa jo kehittämisen alkuvaiheessa. Näin saatu ajatteluperusta siirrettiin ekotuotteistamisessa esitettyyn kansainväliseen elinkaariajattelulähtöiseen markkinointimalliin (Cooper 1990). Markkinointimallia muokattiin siten, että ecodesign sijoitettiin mallin keskiöön ja toiselle puolelle mallia sijoitettiin pienyrityksen kehityskonseptiin liittyvät tekijät. Ecodesignin toiselle puolelle sijoitettiin sidosryhmien vaikutuspiirissä olevat asiat kuten tuotekehitys, markkinointisuunnittelu, hinta ja ecodesign-kriteerit (Kuva $1)$.

\section{Uusi moniääninen ympäristöarvoiltaan erilaistetun tuotteen markkinointimalli}

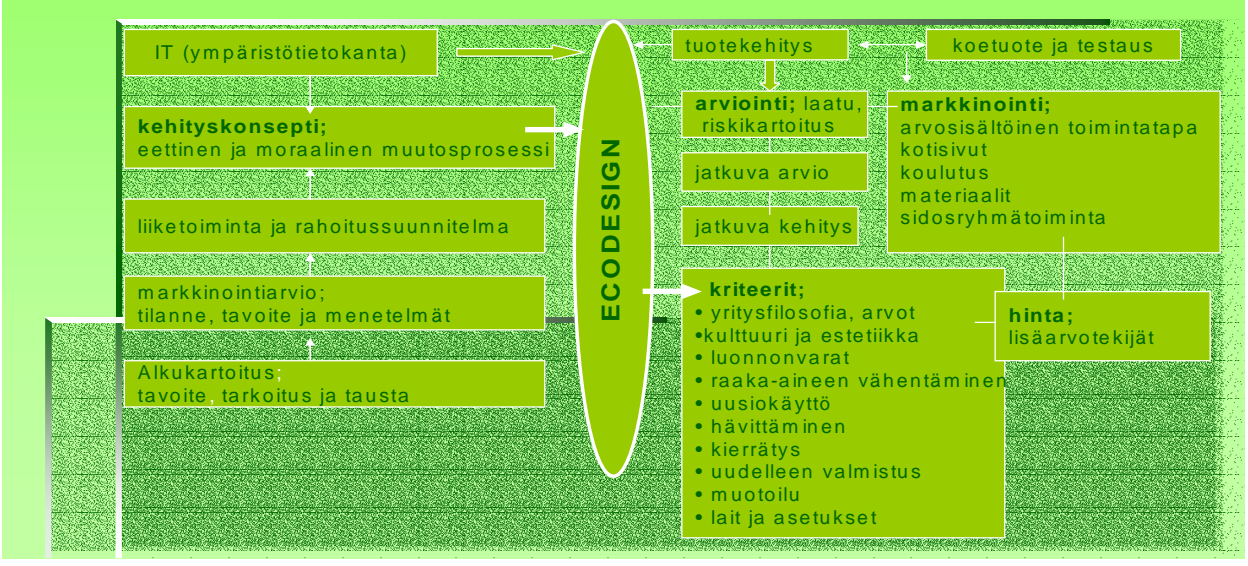

Kuva 1. Ympäristöarvoiltaan erilaistetun tuotteen markkinoinnin lähtökohdat (mukaillen Cooper 1990). 
Ympäristöarvoiltaan erilaistetun tuotteen kehityskonseptin rakentamisen tie kulkee aina ensin pienyrityksen yritystaustan, tavoitteiden ja liiketoimintastrategian kautta. Tämän lisäksi ekotuotteen kehityskonseptin muodostumiseen vaikuttaa yrityksen kyky ja taito hyödyntää erilaisia ympäristötietokantoja. Suomesta ei tällä hetkellä löydy pienyrityksen tarpeisiin suunniteltua ympäristötietokantaa, mutta yritys voi sen rakentaa omia tarpeita vastaavaksi keräämällä tietoja esimerkiksi erilaisten hakurobottien kautta. Ekotuotteen kehityskonsepti on tuotekehityksen ja markkinoinnin työkalu, jota arvioidaan kehityksen eri vaiheissa, ja arviointi on osa markkinointisuunnittelua.

Ympäristöarvoiltaan erilaistetun tuotteen ecodesign-kriteerit luotiin kvalitatiivisen tutkimuksen kautta. Tavoitteena oli kehittää pienyrityksille soveltuva yleinen markkinointimalli, eikä jokaiselle pilot-yritykselle kehitetty omaa tuotekohtaista konseptia markkinointimallin yleistettävyyden vuoksi. Ecodesign-kriteereihin sisällytettiin pilot-yritysten elinkaarilaskelmissa esiin tulleet asiat kuten energian säästäminen ja kierrätys, kulttuuri- ja sosiaaliset arvot sekä ympäristölait ja asetukset. Ecodesignkriteerit muodostuvat aina tuotteeseen yksilöllisinä arvoina, ja markkinoinnin kautta ekotuotteeseen sisällytettävät arvot tulevat kuluttajille läpinäkyviksi.

\section{Johtopäätökset}

Tutkimuksen pienyrityksillä on hyvä perusta ekotuotteistamiseen. Pienyritysten vahvuutena on tuotantoprosessin ja tuotantoympäristön hallinta, mutta heikkoutena ovat eri tekijöiden kuten yritysympäristössä vallitsevien kulttuurisidonnaisen ja sosiaalisen arvoperustan tunnistaminen ja niiden ymmärtäminen osana ekotuotteistamista. Ekotuotteistamisen näkökulmasta pienyrityksen on hyvä tarkastella omaa ekologista asennettaan ja valita niitä tuotteita ekotuotteistamisen piiriin, jotka ovat oman yrityksen kehityskonseptin näkökulmasta optimaalisia. Pienyrityksillä on tällä hetkellä riittävästi valmiuksia ekotuotteistamiseen, jos muutosta tarvitsevat avaintekijät tunnistetaan tuotteessa. Tämän tutkimuksen mukaan avaintekijöiksi ovat muodostuneet yrityksen ympäristöarvojen tunnistaminen, kohtaaminen ja ekotuotteistamisesta viestittäminen perinteisin ja IT-markkinointikeinoin.

Markkinointimallin rakentaminen on osoittanut, että pienyrityksen tie ekoyritykseksi ei ole helppo, vaikka motivaatiota ekotuotteistamiseen yrityksissä onkin. Osa pienyrityksistä pitääkin ehkä ympäristöarvoja niin itsestään selvänä, ettei niitä nähdä potentiaalisina lisäarvon tuottajina eikä niitä näin ollen ole tuotteissa ja palveluissa erityisesti tuotu esille. Ympäristöarvoiltaan erilaistettuihin maaseudun tuotteisiin on kuitenkin tarvetta, jos oletetut ympäristöverot ja muut vastaavat maksut osoitetaan pienyrityksen kustannettavaksi. Elinkaarilaskelmat osoittautuivat pienyrityksille aikaa vieviksi ja kalliiksi, ja pelkästään elinkaarisuuntautunut markkinointi johtaa tekniseen informointiin. Elinkaarilaskelmasuuntautunut ajattelutapa, tuotekehitys ja tuotemarkkinointi eivät ota huomioon yritysympäristöä, sen merkitystä ja ympäristöön sitoutuneita arvoja. Kuitenkin tuotteiden tuotantoprosessit eriytyvät tuotekehityksen kautta, ja tämä mahdollistaa yksilöllisemmän markkinoinnin ja tuotteiden ja palveluiden segmentoinnin niille kuluttajille, jotka ovat valmiita maksamaan ekotuotteista sen arvon mukaisen hinnan. Tutkimuksessa kehitetty pienyritysten markkinointimalli antaa avaimet kohdata muuttuvat ekotuotemarkkinat pienyrittäjien asettamin ehdoin.

\section{Kirjallisuus}

Alasuutari, P. 1994. Laadullinen tutkimus. 3. painos. Tampere: Yliopistopaino. 281 s. ISBN 9519066-75-6

Crawford, C. M. 1996. New products Management. 5. painos. Irwin series in marketing. Chicago. 508 s. ISBN 0-256-18778-9

Charter, M. \& Polonsky, M. J. 1999. Greener Marketing. A Global Perspective on Greening Marketing Practice. Greenlife Publishing Limited. 432 s. ISBN 1874719144

Eskola, J. \& Suoranta, J. 1998. Johdatus laadulliseen tutkimukseen. Lapin Yliopiston kasvatustieteellisiä julkaisuja. Tampere. C 13. 268 s. ISBN 951-768-035-X

Hirsjärvi, S. \& Hurme, H. 1988. Teemahaastattelu. 4. painos. Helsinki: Yliopistopaino. 144s. ISBN 951-570-030-2

Hirsjärvi, S \& Hurme, H. 2000. Tutkimushaastattelu. Teemahaastattelun teoria ja käytäntö. Helsinki: Yliopistopaino. 213 s. ISBN 951-570-458-8

Soini, K. 2000. Johdanto. Julkaisussa: Salo, R., Soini, K. \& Seppälä, A. (toim.). Maaseudun ympäristöarvojen tuotteistaminen - kenellä valta ja vastuu? Maatalouden tutkimuskeskuksen julkaisuja. Sarja A. Jokioinen: Maatalouden tutkimuskeskus. s. 5-8. ISBN 951-729-566-9 